\title{
Management Ecology: A Modern Concept of Sustainable Development for the Digital Economy
}

\author{
Artem Salamatov \\ Department of Economic Theory and Regional \\ Development \\ Chelyabinsk State University \\ Chelyabinsk, Russian Federation \\ salamatov79@mail.ru
}

\author{
Darya Gordeeva \\ Department of Economics, Management and Law \\ South Ural State Humanitarian Pedagogical University \\ Chelyabinsk, Russian Federation \\ gordeeva.darya@mail.ru
}

\author{
Vladimir Belevitin \\ Department of Transport, Information Technologies and Methods of Teaching Technical Disciplines \\ South Ural State Humanitarian Pedagogical University \\ Chelyabinsk, Russian Federation \\ belewitina@rambler.ru
}

\begin{abstract}
In the article, the authors raise the question of developing a modern concept of sustainable development for the digital economy - the concept of "management ecology" - an innovative research area, which includes a complex system of high-tech educational and financial-economic forms of management in a market economy, which implements the functions of organizing, controlling, motivating and coordinating production activities, focusing on environmental and economic safety requirements and providing a program for solving problems sustainable development. Adopting this concept as a methodological basis for sustainable development will allow us to study the behavior of organizations using integrated environmental and economic approaches, develop a system of indicators that regulate the magnitude of external influences under the conditions of tolerance of environmental and economic systems, and build adequate economic and mathematical models of the organization's strategic response to environmental economic threats to safe functioning, design a graduate-manager model who is ready to realize not the declared, but the actual goals of sustainable development of society.
\end{abstract}

Keywords: sustainable development, environmental and economic safety, concept, management ecology, digital economy

\section{INTRODUCTION}

The current stage of development of the world economy indicates that more and more persistently economic efficiency is opposed to environmental friendliness of production, and susceptibility to eco-innovations in developed countries, and even more so in developing ones, does not stand up to criticism - only a small percentage of the largest corporations develop and implement environmental technological innovations. The environmental and economic responsibility of business as part of the development strategy of enterprises is often focused only on cost reduction when paying environmental fees and taxes, and to a greater extent is a manifestation of the advertising and marketing effect, but it is not aimed at environmental and economic safe activity and does not contribute to sustainable development of society (Bobylev, S.N., Davankov, A.Yu., Brown, L.R., Belkin, V.N.) $[1 ; 2 ; 3]$.

Management ecology is a qualitatively new, but regular stage in the development of managerial thought, focused on the principle of creating parity opportunities for the development of socio-economic and natural systems. The study of the behavior of organizations using integrated environmental and economic approaches, the development of a system of indicators governing the magnitude of external influences according to the conditions of tolerance of environmental and economic systems, the construction of an adequate economic and mathematical model of the organization's strategic response to environmental and economic threats to safe functioning, as well as the construction of a graduate model a manager who is ready to implement not the declared but the actual goals of sustainable development of society, will give focus and specific studies in the designated area of concern.

\section{MethodOLOGY}

An analysis of Russian and foreign sources on the studied issues showed that the goals and conceptual foundations of the ecology of management, its categorical apparatus should be developed, on the one hand, with a focus on global trends in the transformation of environmental and economic aspects of 
the functioning of business systems, and on the other hand, in line with national characteristics of understanding the socioecological and economic processes taking place in Russia (Bobylev, S.N., Solovyeva, S.V., Komarov, V., Salamatov A.A., Gordeeva, D.S.) $[4 ; 5 ; 6 ; 7 ; 8]$.

The process of establishing a new attitude to the natural environment was an integral part of the general, global change of scientific, philosophical, ethical and social values of the management sphere. Managers turn to the environmental aspects of the use of natural resources, realizing the impossibility of further economic development without taking into account the consequences of nature as one or another managerial decision is made. The essence of these changes lies in the fundamental transitions from mechanical to organic, from materialism to spirituality, from antagonism to unity. The convergence of parallel evolving environmental and economic paradigms is also evident.

At the present stage of development of society, two concepts of the interaction of society with the environment prevail - the concept of sustainable development and the concept of environmental modernization. Both concepts appeared at about the same time, but a careful analysis of the scientific literature indicates the extreme popularity of mentioning the provisions of sustainable development, while environmental modernization is popular with a narrow circle of authors (Hovardas, T., Kudinova, G.E., Lazareva, N.V., Rozenberg, G.S., Rozenberg, A.G., Kostina, N.V.) [9; 10; 11].

The idea of the concept of sustainable development has an extensive theoretical base, is generally accepted and understandable for the entire world community (Mella, P., Gazzola, P.) [12], but nevertheless, almost at the same time another theory arose - the concept of environmental modernization, which has become an integral part of the global scientific discussion (Shkarupa, O.V., Karintseva, O.I., Shkarupa, I.S.) [13]. Compliance with stringent environmental requirements is not currently an obstacle to economic development. This is an effective mechanism that stimulates progressive structural transformations that outstrip the development of high-tech and resource-saving industries and industries in the modern world, which determine the status and competitiveness of the national economy. Unfortunately, the postulates of the concept of sustainable development, being, of course, fundamental and indisputable, remain a convenient passive dogma, the provisions of the concept of environmental modernization are being dynamically implemented, but, for a number of reasons, are far from universal. We believe that in a digital economy it is necessary to determine a clearly oriented azimuth of further environmental and economic development, the urgent process of changing priorities in the field of ecology and management, choose a new paradigm that will be accepted by the majority - the concept of "management ecology" (Salamatov, A.A., Gordeeva, D.S.) [14].

\section{RESULTS}

It is necessary to clearly define the essential characteristics of indicators that can be used in the selection of criteria for constructing an economic-mathematical model when crossing four areas:
1. Human potential. In modern society, the analysis of human potential includes the assessment or conditional accounting of its intellectual stock and future opportunities. The problem of preservation, development and realization of human potential is a subject of increased and alarming public attention. The extraction, exploitation and sale of natural resources at the present stage of economic development is actually the main source of income for most developing countries. The disadvantages of this strategy are manifested in all areas of public life: socio-cultural, economic, international relations, etc. It is necessary to choose a new development strategy, an innovative promising path based on the development of new technologies, where the decisive role is played by the intellectual forces of society.

Criteria for the econometric model in the context of human potential:

- optimization of economic relations with business;

- personality orientation (motives, needs, interests);

- value orientations.

2. Production. The existing diverse organizational forms of business are the result of "natural selection" in the course of market competition, and one optimal organizational form does not exist - in different conditions, different forms will be optimal.

Criteria for the econometric model in the context of the business sphere:

- integration of manufacturability and environmental friendliness of production;

- transparent relations with the state;

- Improving the process of environmental control and monitoring through innovative technologies;

- optimization of the process of distribution of natural raw materials;

- cost minimization while ensuring environmental friendliness of the production sector.

3. Science and education. Education in the modern world, which is a connecting factor between the effective functioning of a business and ecological well-being in general, performs two global functions - noo-humanistic (orientation of the educational process on the survival strategy of mankind) and environmental (emphasized on careful attitude to nature, formation of the noosphere type of thinking). Science and research activities, derived from the outside of a simple consumer, contribute to the development and development of new environmentally friendly production technologies.

Criteria for the econometric model in the context of science and education:

- improving living standards through scientific patents and research, which are innovatively applied at the outlet;

- the use of new educational developments, systems and services with the aim of forming the personality of a 
specialist, ready for internal changes and changes in the environment;

- Digitalization of the learning process in order to create an educational ecosystem that meets the challenges of our time.

4. The environment. The boundaries of the environment determine the biophysical boundaries within which humanity can flourish. There are undoubtedly many ways that can ensure inclusive and sustainable development in this space. The EU's 7th Environmental Action Plan aims to build longterm sustainability so that, by 2050 , humanity can live within the planet's environmental constraints. This concept is based on smart citizenship that brings people and technology together to create an innovative, sustainable knowledge economy.

\section{DISCUSSION}

The assimilation potential of the environment, its ability to self-healing is almost exhausted. It is necessary to develop relations between organizations (human potential) and the environment (resource potential), taking into account the experience of historically established managerial concepts, perceiving difficulties and mistakes as some kind of relativism, without which success cannot be achieved.

The digital economy acts as a very effective mechanism for the ecology of management, allowing us to consider the socio-economic system from the position of ecologicallyeconomically consolidated, that is, a system that has qualitative and quantitative environmental and economic indicators integrated without loss of individualization of each sphere individually (Rappitsch, Ch.) [15]. The development of a theoretical justification of the processes of formation and functioning of border zones at the junction of co-evolving antagonistic systems of production and the natural spheres (based on the principle of creating parity opportunities for the development of the organizational and natural environment) will expand managerial capabilities and will significantly increase labor productivity with minimal transport and transactional and resource costs, will effectively orient bifurcation processes on the positive environmental and economic effect (Davankov, A.Yu., Dvinin, D.Yu., Postnikov, E.A.) [16]. The identified problem is complex and includes three areas:

- based on the knowledge of the laws of nature, compiling a matrix of indicators governing the magnitude of external loads according to its tolerance;

- creating, on the basis of knowledge of the laws of development of the production sphere of technology, which will stabilize the level of external influences in biologically sound ranges;

- building a high-quality econometric model based on S.P.A.C.E.-analysis that clearly demonstrates the strategic pursuit of interests and a possible sustainable ecological and economic future.
We are convinced that the concept of "management ecology" has its potential in this regard and is fully consistent with the innovation of the digital economy.

\section{Acknowledgment}

The reported study was funded by RFBR, project number 19-29-07209.

\section{References}

[1] S.N. Bobylev, "Sustainable development: a paradigm for the future", World Economy And International Relations, vol. 61 (3), pp. 107-113, 2017.

[2] L.R. Brown, Ecoeconomics: how to create an economy that protects the planet. Trans. from English, M.: The whole world, 392 p., 2003.

[3] V.N. Belkin and G.N. Pryakhin, Socio-ecological and economic factors of the quality of life of the population of the region: collective monograph. Chelyabinsk: Encyclopedia, 344 p., 2019.

[4] S.N. Bobylev and S.V. Solovyeva, "Sustainable development goals for the future of Russia", Studies on Russian Economic Development, t. 28 (3), pp. 259-265, 2017.

[5] V. Komarov, "The strategy of economic development: is it time to update the paradigm?", Ekonomicheskaya Politika, vol. 10 (6), pp. 2439, 2015.

[6] A.A. Salamatov, "Ecological and economic security of Russia: the future in retrospect. Part One", Socium and Power, no. 1 (51), pp. 102$108,2015$.

[7] A.A. Salamatov, "Ecological and economic security of Russia: the future in retrospect. Part Two", Society and Power, no. 2 (52), pp. 7481, 2015.

[8] P. Ryabchuk, A. Salamatov, and D. Gordeeva, "Eco-Economic Security of the Region: Expanding the Management System for Assessing the State of Development", International Journal of Supply Chain Managemen, vol. 7, no. 6 (201), 2018.

[9] T. Hovardas, "Two paradoxes with one stone: A critical reading of ecological modernization”, Ecological Economics, vol. 130, pp. 1-7, 2017.

[10] G.E. Kudinova, N.V. Lazareva, G.S. Rozenberg, and A.G. Rozenberg, "Environmental modernization - new solutions in the transformation of the world economy", GCPMED 2018, International Scientific Conference "Global Challenges and Prospects of the Modern Economic Development": European Proceedings of Social and Behavioural Sciences, vol. 57, pp. 1491-1497, 2019.

[11] G.S. Rozenberg, N.V. Kostina, G.E. Kudinova, and A.G. Rozenberg, "Environmental modernization: the basin approach on the example of the largest rivers in Asia and Europe", Bulletin of the Samara State University of Economics, t. 8, pp. 25-34, 2014.

[12] P. Mella and P. Gazzola, "Sustainability and quality of life: the development model", Enterprise and the Competitive Environment, vol. 2, pp. 542-551, 2015.

[13] O.V. Shkarupa, O.I. Karintseva and I.S. Shkarupa, "Innovation potential of ecological modernization for green growth of economics: a case study", International Journal of Ecology \& Development, vol. 31, pp. 73-80, 2016.

[14] A.A. Salamatov, E.A. Gnatyshina, and D.S. Gordeeva, "The concept of sustainable environmental and economic development in the transition to the digital economy", Proceedings of the International Scientific and Practical Conference on Digital Economy, ISCDE 2019, pp. 857-862, 2019.

[15] Ch. Rappitsch, "Digital Economy and Sustainability", OIKOS, 2017.

[16] A.Yu. Davankov, D.Yu. Dvinin, and E.A. Postnikov, "Methodological tools for assessing the socio-ecological and economic environment regions within the boundaries of the biosphere stability", Economy of the region, t. 12, iss. 4, pp.1029-1039, 2016. 